\title{
Description of Neblinichthys brevibracchium and N.echinasus from the upper Mazaruni River, Guyana (Siluriformes: Loricariidae), and recognition of $N$. roraima and $N$. yaravi as distinct species
}

\author{
Donald C. Taphorn ${ }^{1}$, Jonathan W. Armbruster ${ }^{2}$, Hernán López-Fernández ${ }^{3}$ \\ and Calvin R. Bernard ${ }^{4}$
}

\begin{abstract}
Neblinichthys brevibracchium and $N$. echinasus are new sympatric species from upland tributaries of the Mazaruni River (Essequibo River basin) of Guyana. These two new species are the first Neblinichthys reported from Guyana. Adult males of both new species have short pectoral-fin spines and several series of hypertrophied odontodes covering the entire dorsal surface and along the entire edge of the snout. They are distinguished from each other by dorsal-fin base length/standard length (18.1-22.8\% in N. brevibracchium vs. 24.3-27.0\% in N. echinasus), dorsal-anal distance/SL (13.7-18.3\% in N. brevibracchium vs. $11.9-12.5 \%$ in $N$. echinasus), by having the snout decreasing in steep arc just anterior to eyes and then flattening in area anterior of nares in $N$. brevibracchium vs. the snout tapering shallowly and continuously from eyes to snout tip in N. echinasus); and by having the adpressed dorsal fin reaching the anterior preadipose plate in $N$. brevibracchium (vs. not reaching anterior preadipose plate in $N$. echinasus). They are distinguished from all congeners by lacking odontodes on the opercle ( $v s$. odontodes present); and by completely lacking an iris operculum ( $v s$. congeners with small iris operculum present or at least dorsal portion of iris flat instead of rounded). Neblinichthys echinasus and N. brevibracchium differ from all congeners by having a spotted or vermiculated pigment pattern on the abdomen (vs. abdomen plain); in N. echinasus the abdomen is darkly pigmented with bold white spots and in Neblinichthys brevibracchium the abdomen is light-colored with gray spots and vermiculations. Neblinichthys brevibracchium and $N$. echinasus differ from $N$. roraima by having one to two preadipose plates (vs. four or more). New observations revealed Neblinichthys roraima and $N$. yaravi to be distinct, with $N$. roraima having four or more preadipose plates and $N$. yaravi having one or two. Both are present in the upper río Caroní, an Orinoco tributary that drains the slopes of Mount Roraima and other mountains of the Pacaraima Range in Venezuela and interdigitates with headwaters of the Mazaruni River.
\end{abstract}

Neblinichthys brevibracchium y N. echinasus son especies nuevas simpátricas que viven en las cabeceras del río Mazaruni (cuenca del río Essequibo) en Guyana. Estas dos especies nuevas son las primeras Neblinichthys registradas de Guyana. Se distinguen uno del otro por la relación de la longitud de la base de la aleta dorsal/SL (18,1-22,8\% in N. brevibracchium vs. 24,3-27,0\% en $N$. echinasus), por la distancia dorsal-anal/SL (13,7-18,3\% en $N$. brevibracchium vs. 11,9-12,5\% en $N$. echinasus), por el hocico que declina suavemente desde los ojos hacia la punta ( $v s$. hocico que declina abruptamente desde los ojos hasta la punta) y en tener una aleta dorsal que alcanza la placa pre-adiposa anterior cuando se aprieta al cuerpo ( $v s$. no alcanzando la placa pre-adiposa anterior). Se distinguen de todos sus congéneres por carecer de odontodos en el opérculo, y por la falta del iris opérculo en el ojo ( $v s$. presencia de un iris opérculo pequeño o al menos con la parte dorsal del iris plana en vez de redondeada). Los machos adultos de ambas especies nuevas tienen las espinas pectorales cortas y tienen varias series de "pelos" (odontodos hipertrofiados) cubriendo la superficie dorsal entera y los bordes laterales del hocico. Neblinichthys echinasus se distingue de todos sus congéneres excepto $N$. brevibracchium por tener un patrón llamativo de vermiculaciones blancas en el abdomen y de $N$. roraima por tener una o dos placas preadiposas ( $v s$. más de cuatro). Neblinichthys brevibracchium difiere de todos sus congéneres por tener el abdomen de color claro con manchas y vermiculaciones grises con la cabeza y cuerpo más profundo y de $N$. roraima se distingue en tener una o dos placas preadiposas ( vs. cuatro o más). Nuevas observaciones muestran que Neblinichthys roraima y $N$. yaravi son diferentes: $N$. roraima tiene cuatro o más placas preadiposas y $N$. yaravi tienen una o dos. Ambas especies están presentes en alto río Caroní, un tributario del río Orinoco que drena las laderas occidentales del monte Roraima y otras montañas de la Sierra de Pacaraima en Venezuela.

Key words: Essequibo, Guiana Shield, Isolation, Endemism, Punk Catfish.

\footnotetext{
${ }^{1} 1822$ N. Charles St., Belleville, IL, USA. taphorn@gmail.com

2Department of Biological Sciences, Auburn University, 331 Funchess, Auburn, AL 36849, USA. armbrjw@auburn.edu

${ }^{3}$ Department of Natural History, Royal Ontario Museum, 100 Queen's Park, Toronto, Ontario M5S 2C6, Canada, and Department of Ecology and Evolutionary Biology, University of Toronto, 25 Willcocks Street, Toronto, Ontario M5S 3B2, Canada. hernanl@rom.on.ca ${ }^{4}$ Center for the Study of Biodiversity, University of Guyana, Georgetown, Guyana. calrber@gol.net.gy
} 


\section{Introduction}

Ferraris et al. (1986) described Neblinichthys pilosus, a new genus and species of loricariid catfish now in the subfamily Hypostominae, tribe Ancistrini (sensu Armbruster, 2004a). Neblinichthys pilosus is found in the upper Pasimoni River, which drains the northern slopes of the Sierra de la Neblina, the western margin of the Guiana Shield, in southernmost Venezuela, and is a tributary to the río Casiquiare. The new genus was primarily diagnosed by a derived secondary sexual character of adult males: strikingly elongated odontodes on the dorsal surface of the snout that project anteriorly, a feature that has marveled both ichthyologists and aquarists, and led to the name of "Punk Catfish" in the popular press. Armbruster (2004a, 2008) suggested an additional unique synapomorphy for Neblinichthys: the opercular condyle of the hyomandibula is located on a process extended beyond the posterior margin of the main body of the hyomandibula. Armbruster (2008) found Neblinichthys to be sister to a clade containing Ancistrus, Lasiancistrus, Chaetostoma, Cordylancistrus, Dolichancistrus, Exastilithoxus, Hopliancistrus, Lithoxus, Pseudolithoxus, and New Genus 2.

A second species, Neblinichthys roraima, was described from the upper Caroní River, a tributary of the Orinoco River draining the tepui region of the Gran Sabana in southeastern Venezuela (Provenzano et al., 1995). This species was thought to be a synonym of N. yaravi (Steindachner, 1915), (Ferraris, 2007; Armbruster, 2008). Although the type of Ancistrus yaravi is apparently lost, the original description by Steindachner describes a fish with the pectoral and pelvic fins of the same length and the only ancistrins in the Caroní River drainage with this trait are species of Neblinichthys and Pseudancistrus reus (Armbruster \& Taphorn, 2008). The original description offers few other clues of what the fish might be, but we have identified two distinct species of Neblinichthys in the upper Caroní. We here identify one species as $N$. yaravi and leave $N$. roraima as a valid species for the other.

We have discovered two new species of Neblinichthys in the upper Mazaruni River, Essequibo River drainage, Guyana. These two species differ from all other Neblinichthys by lacking odontodes on the opercle, and by having most of the odontodes arranged along the anterior and lateral margins of the snout in a pattern similar to that of some other ancistrins (like Pseudancistrus and Lasiancistrus) in addition to having slightly shorter odontodes directed dorsally on the snout. The species are located on the northeast side of Mount Roraima opposite from $N$. roraima and $N$. yaravi.

Species of the somewhat similar genus Pseudancistrus also have hypertrophied odontodes along the margin of the snout, but have much longer pectoral spines than Neblinichthys, have the hypertrophied odontodes restricted to the edge of the snout ( $v s$. also on the dorsal surface of the snout), have four or five rows of plates on the caudal peduncle (vs. three), have an iris operculum ( $v s$. absent in the new species), and are diagnosed by several synapomorphies not found in Neblinichthys (Armbruster, 2004b; Lujan et al., 2007).

\section{Material and Methods}

Counts and measurements follow Armbruster (2003). Institutional abbreviations are as in Leviton \& Gibbs (1988) except for that of the Ichthyology Collection at the Center for the Study of Biodiversity at the University of Guyana (CSBD). Names of plate rows follow Schaefer (1997). Data for all species of Neblinichthys are provided in Tables 1-2. We used Eschmeyer (2008) to check species names and references. Sex was presumed based on the presence of hypertrophied odontodes on the snout being present or developing; however, some ancistrins have both males and females with hypertrophied snout odontodes (Armbruster \& Provenzano, 2000).

\section{Results}

\section{Neblinichthys brevibracchium, new species Fig. 1}

Holotype. CSBD 1653 (ex ROM 83772), 73.3 mm SL, presumably male, Guyana, upper Mazaruni River drainage, mouth of a small creek with cut banks and primary forest, lower Kukui River at Jawalla, 05³9'10”N 60²8'57’W, 20 Apr 2008, H. LópezFernández, D. C. Taphorn, E. Liverpool, K. Kramer \& C. Thierens.

Paratypes. All from Guyana, upper Mazaruni River drainage, collected by H. López-Fernández, D. Taphorn, E. Liverpool, K. Kramer \& C. Thierens: ROM 83684, 4, 19.5-30.9 mm SL, AUM 50302, 1, $78.8 \mathrm{~mm}$ SL, Kukui River upstream of Philipai, $05^{\circ} 22^{\prime} 05^{\prime} \mathrm{N} 60^{\circ} 21^{\prime} 59^{\prime}$ 'W, 16 Apr 2008. ROM 83692, 4, 58.1$79.9 \mathrm{~mm}$ SL, Kukui River in and around Philipai, 05 21'37'N $60^{\circ} 22^{\prime} 18^{\prime \prime} \mathrm{W}, 16$ Apr 2008. ROM 83695, 1, 68.0 mm SL, Kukui River at Philipai, $05^{\circ} 21^{\prime} 37^{\prime \prime N} 60^{\circ} 22^{\prime} 18^{\prime \prime} \mathrm{W}, 16$ Apr 2008. AUM 50303, 1, 57.3 mm SL, ROM 83697, 3, 35.6-62.0, Kukui River around Philipai, $05^{\circ} 21$ '37'N 60²2'18”'W, 16 Apr 2008. AUM 50304, 2, 47.7-60.8 mm SL, ROM 83713, 5, 29.0-65.6 mm SL, Kukui River upstream from Philipai, $05^{\circ} 21^{\prime} 37^{\prime \prime N} 60^{\circ} 22$ ' $18^{\prime}$ 'W, 17 Apr 2008. ROM 83739, 2, 40.9-56.9 mm SL, Mazaruni River, sandy beach at the confluence of the Mazaruni River and the Kukui River, $05^{\circ} 40^{\prime} 21^{\prime} \mathrm{N} 60^{\circ} 28^{\prime} 59^{\prime}$ W, 17 Apr 2008. ROM 83785,2 , 58.8-60.3 mm SL, Waruma River, riffles and shallow

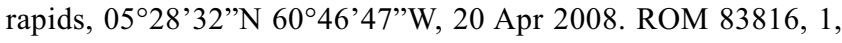
$60.4 \mathrm{~mm} \mathrm{SL}$, Waruma River, shallow pool, $05^{\circ} 28^{\prime} 32^{\prime \prime} \mathrm{N}$ 6046'47'W , 21 Apr 2008. ROM 83828, 1, $63.6 \mathrm{~mm}$ SL, rapids on Paikwa River, $05^{\circ} 29^{\prime} 00^{\prime}$ N 6043'56”W, 22 Apr 2008. ROM $83841,1,54.1 \mathrm{~mm}$ SL, rapids on Paikwa River, $05^{\circ} 29^{\prime} 10^{\prime \prime} \mathrm{N}$ $60^{\circ} 43^{\prime} 57^{\prime}$ 'W, 22 Apr 2008. ROM 83853, 1, 61.2 mm SL, Paikwa River drainage, Sedaa creek, at lowermost rapids, $05^{\circ} 41^{\prime} 18^{\prime \prime} \mathrm{N}$ $60^{\circ} 40^{\prime} 43$ ”'W, 23 Apr 2008.

Diagnosis. Neblinichthys brevibracchium can be separated from all congeners except $N$. echinasus by lacking odontodes on the opercle (rarely one odontode present, $v s$. the exposed portion of the opercle completely covered in odontodes), by completely lacking the iris operculum ( $v s$. iris operculum small or at least the dorsal rim of the pupil straight), and internares width/head length ratio (5.0-8.5\% vs. 7.6-15.5\%, 


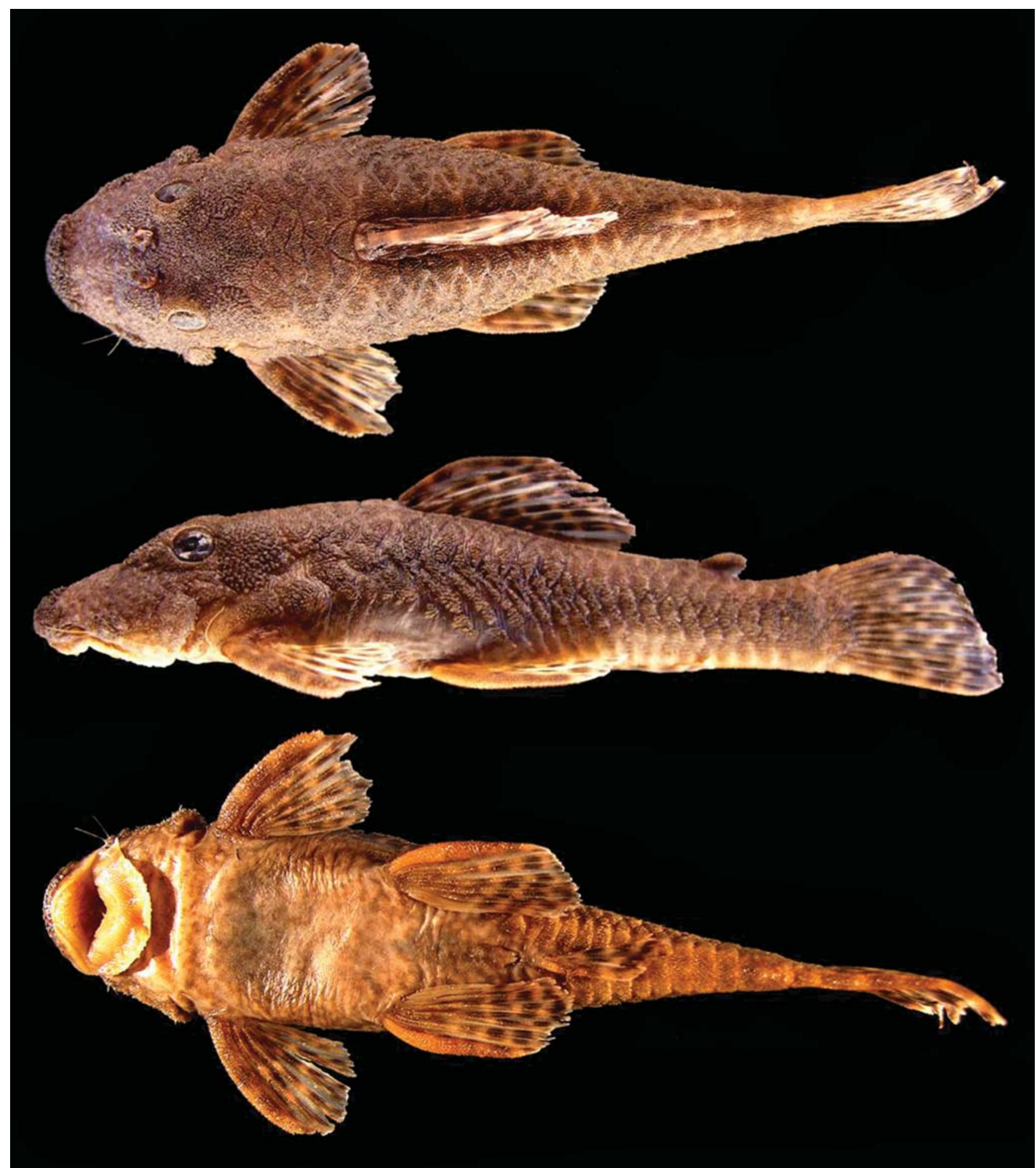

Fig. 1. Neblinichthys brevibracchium, holotype, CSBD 1653, 73.3 mm SL, lower Kukui River at Jawalla, upper Mazaruni River drainage, Guyana.

see Tables 1-2), and by having irregular gray spots and vermiculations on the abdomen of adults ( $v s$. no markings); from $N$. roraima by having one to two preadipose plates ( $v s$. more than four); and from N. echinasus by a smaller dorsalfin base length/SL ratio (18.1-22.8\% vs. 24.3-27.0\%), a larger dorsal-anal distance/SL ratio (13.7-18.3\% vs. 11.9-12.5\%), by having the snout decreasing in steep arc just anterior to eyes and then flattening in area anterior of nares ( $v s$. snout tapering shallowly and continuously from eyes to snout tip; Fig. 1), and by having the adpressed dorsal fin not reaching the anterior preadipose plate ( $v s$. reaching anterior preadipose plate). 
Table 1. Morphometric features of Neblinichthys brevibracchium, new species $(\mathrm{N}=11)$ and $N$. echinasus, new species $(\mathrm{N}=3)$. Landmarks are the numbered landmarks in Armbruster (2003).

\begin{tabular}{|c|c|c|c|c|c|c|c|}
\hline \multirow[b]{2}{*}{ Landmarks } & \multirow[b]{2}{*}{ Feature } & \multicolumn{3}{|c|}{ N. brevibracchium } & \multicolumn{3}{|c|}{ N. echinasus } \\
\hline & & Holotype & Mean \pm SD & Range & Holotype & Mean \pm SD & Range \\
\hline \multicolumn{8}{|c|}{ Percents of standard length } \\
\hline $1-7$ & Head length & 32.6 & $35.0 \pm 1.4$ & $31.1-39.7$ & 35.4 & $32.8 \pm 0.3$ & $32.6-33.1$ \\
\hline $7-10$ & Head-dorsal length & 8.8 & $11.4 \pm 1.2$ & $9.4-14.0$ & 10.7 & $10.2 \pm 1.7$ & $8.8-12.0$ \\
\hline $8-9$ & Cleithral width & 27.2 & $27.9 \pm 1.3$ & $23.9-29.7$ & 29.3 & $26.8 \pm 0.7$ & $26.0-27.3$ \\
\hline $12-29$ & Pectoral-spine length & 19.3 & $21.1 \pm 1.5$ & $17.5-23.6$ & 20.2 & $20.9 \pm 1.7$ & $19.3-22.7$ \\
\hline $13-14$ & Abdominal length & 21.6 & $22.5 \pm 1.1$ & $19.5-24.3$ & 22.0 & $22.7 \pm 1.4$ & $21.6-24.3$ \\
\hline $13-30$ & Pelvic-spine length & 21.1 & $21.4 \pm 1.5$ & $18.6-24.5$ & 20.7 & $21.3 \pm 0.7$ & $20.8-22.1$ \\
\hline $14-15$ & Postanal length & 31.0 & $30.8 \pm 1.3$ & $28.4-33.0$ & 30.5 & $32.4 \pm 1.2$ & $31.0-33.2$ \\
\hline $14-31$ & Anal-fin spine length & 10.2 & $11.5 \pm 1.3$ & $9.4-15.0$ & 12.6 & $8.8 \pm 2.0$ & $6.6-10.2$ \\
\hline $16-17$ & Dorsal-adipose distance & 19.0 & $19.1 \pm 1.9$ & $16.5-26.3$ & 19.8 & $17.4 \pm 1.4$ & $16.4-19.0$ \\
\hline $17-18$ & Adipose-spine dength & 8.1 & $7.6 \pm 0.8$ & $6.1-9.5$ & 7.0 & $7.9 \pm 0.4$ & $7.3-8.1$ \\
\hline $17-19$ & Adipose-up. caudal distance & 12.8 & $16.2 \pm 1.1$ & 13.4-18.9 & 17.1 & $15.1 \pm 2.0$ & $12.8-16.8$ \\
\hline $15-19$ & Caudal peduncle depth & 9.0 & $9.7 \pm 0.8$ & $8.4-11.3$ & 10.5 & $8.8 \pm 0.2$ & $8.6-9.0$ \\
\hline $15-17$ & Adipose-low. caudal distance & 17.7 & $20.7 \pm 0.9$ & $18.8-22.7$ & 21.7 & $20.4 \pm 2.4$ & $17.7-22.2$ \\
\hline $14-17$ & Adipose-anal distance & 19.3 & $19.0 \pm 0.8$ & $17.0-20.5$ & 19.6 & $17.9 \pm 1.2$ & $17.0-19.3$ \\
\hline $14-16$ & Dorsal-anal distance & 12.4 & $16.4 \pm 1.1$ & $13.7-18.3$ & 17.8 & $12.3 \pm 0.3$ & $11.9-12.5$ \\
\hline $13-16$ & Pelvic-dorsal distance & 22.8 & $22.6 \pm 1.4$ & $19.9-26.3$ & 22.6 & $21.0 \pm 1.6$ & $19.6-22.8$ \\
\hline \multicolumn{8}{|c|}{ Percents of head length } \\
\hline $5-7$ & Head-eye length & 25.7 & $27.5 \pm 1.5$ & $25.4-33.6$ & 25.4 & $27.4 \pm 1.5$ & $25.7-28.2$ \\
\hline $4-5$ & Orbit diameter & 11.6 & $11.9 \pm 0.8$ & $10.3-13.5$ & 11.8 & $13.4 \pm 1.6$ & $11.6-14.6$ \\
\hline $1-4$ & Snout length & 49.3 & $44.8 \pm 1.9$ & $41.1-48.3$ & 46.4 & $46.7 \pm 2.3$ & $44.8-49.3$ \\
\hline $27-28$ & Premaxillary tooth cup length & 10.3 & $10.3 \pm 1.1$ & $8.2-12.3$ & 9.2 & $9.5 \pm 1.5$ & $7.8-10.4$ \\
\hline
\end{tabular}

Description. Morphometrics presented in Table 1. Meristics based on 11 individuals, from total of 29 examined. Largest specimen: $79.9 \mathrm{~mm}$ SL. Nuptial males not observed.

Body relatively deep, not particularly dorsoventrally flattened as in other species of Neblinichthys. Caudal peduncle laterally compressed. Profile from tip of snout to nares concave, angled up at about $45^{\circ}$, slightly convex to dorsal-fin origin. Orbits slightly elevated above head profile. Deepest point of body just anterior to dorsal fin. Profile straight or gently concave to adipose-fin origin, then slightly concave to base of upper caudal-fin spine. Ventral surface flat or slightly concave from just behind oral disk to anal-fin origin then straight to base of lower caudal spine. Eyes widely separated, laterally oriented, not visible from below. Dorsal profile of head as shown in Fig. 1. Body widest just anterior to dorsal-fin origin, narrowing slightly until posterior margins of pelvic fins, and then quickly tapering to end of caudal peduncle.

Anterior margin and dorsal surface of snout with small odontodes. No large hypertrophied odontodes present in any specimens examined. Cheek plates only moderately evertible (not reaching to $90^{\circ}$ from head), cheek odontodes short, tiny, and very numerous. Snout tip wide and with protuberant patch of odontodes, odontode bearing raised crests extend along margins of snout, and down dorsal midline of snout. Another elevated patch of odontodes extending short distance anterior from orbit. Iris operculum absent, making dorsal rim of pupil round.

Mouth moderate in size with narrow premaxillary and dentary tooth cups forming gentle arcs. Premaxillary teeth 32-58; dentary teeth 30-72. Teeth villiform and bicuspid with very short cusps (medial cusp longer than lateral). Edge of oral disk scalloped, and extending to vertical through anterior margin of eye, not extending beyond lateral margins of head. Enlarged central papilla present in buccal cavity. Maxillary barbel very short, not reaching base of evertible cheek plates. Ventral surface of lips papillose. Papillae largest in center of lower lip, decreasing radially. No enlarged papillae located behind dentary teeth.

Dorsal fin II,7; dorsal-fin spinelet flat platelet with short odontodes. Dorsal fin short, not reaching preadipose plate when adpressed. First dorsal-fin ray slightly longer than dorsal-fin spine. Pectoral fin I,6. Pectoral-fin spine short (about equal to pelvic-fin spine) not reaching pelvic fin when adpressed; 
relatively weak, numerous odontodes of equal size present along entire length. Anterior pectoral-fin rays longer than pectoral-fin spine, decreasing to about half of length of spine posteriorly, covered with odontodes, largest on dorsal surface. Pelvic fin I,5; thickened and covered with odontodes, reaching into anterior third of anal-fin base when adpressed; anterior pelvic-fin rays longer than pelvic-fin spine with posterior margin of fin curving out beyond posterior tip of spine. Anal fin I,5; all anal-fin rays slightly longer than odontode-covered weak spine. First anal-fin pterygiophore not exposed to form platelike structure. Adipose-fin spine straight to slightly curved posteriorly with adipose membrane extending beyond posterior extent of spine. Caudal fin I,14,I; upper caudal-fin spine shorter than first two upper rays, lower spine longer than all rays, and much longer than upper spine. Dorsal procurrent caudal-fin rays five (six in one specimen), ventral procurrent caudal-fin rays three. Posterior caudal-fin margin slightly concave. Rays of all fins supporting small odontodes.

Median plate series with 21-23 plates, not counting those on base of caudal fin. Ventral plates forming gentle arc on caudal peduncle and not forming strong rounded keel. Plates in mid-ventral row weakly arched submedially forming low ridge from cleithrum to posterior insertion of pelvic fin. Three rows of plates on caudal peduncle (mid-dorsal plate series ending at level of adipose fin). Abdomen naked.

Coloration in alcohol. Head, dorsum of body and sides tan to dark brown with irregular, darker brown or black spots and blotches. No individuals showing regular rows of spots. Ventrum light colored, whitish or light tan with irregular spots and vermiculations, pattern strongest anteriorly just behind oral disk. Oral disk with inner papillated surfaces pale tan; upper lip's outer anterior margin darkly mottled. All fin spines and rays with alternating wide dark and narrow light bands (pattern evident in all fins of most individuals); fin membranes hyaline, not pigmented. Dark spot present at base of anteriormost dorsal-fin membrane (Fig. 1).

Sexual dimorphism. Presumed males appear to have either recently lost hypertrophied snout odontodes, or are just gaining them. The area at the tip of the snout has enlarged papillae that appear to presage the development of hypertrophied odontodes in ancistrins (JWA, pers. obs.). There is a small region, about one and a half eye diameters, that is without noticeable odontode hypertrophication and is followed by region of about one and a half eye diameters with mildly hypertrophied odontodes (holotype has two very long odontodes on the left side in this region), followed by a region preceding the gill opening where we observe a very slight increase in size of odontodes (Fig. 1). The preorbital ridge appears thickened and has some relatively elongate odontodes suggesting that this area may also develop hypertrophied odontodes. Given the presence of two very long odontodes on the snout of the holotype, we presume that nuptial males have more extensive ornamentation.
Distribution. Known from upper Mazaruni River, Essequibo drainage, Guyana (Fig. 2).

Etymology. From the Latin words brevis which means short, and bracchium meaning forearm, in reference to the relatively short pectoral spines present in Neblinichthys. Epithet used as a noun in apposition, in masculine form.

\section{Neblinichthys echinasus, new species} Fig. 3

Holotype. CSBD 1652, ex (ROM 83713), $82.9 \mathrm{~mm}$ SL, presumably male, Guyana, upper Mazaruni River drainage, Kukui River, near town of Philipai, $05^{\circ} 21^{\prime} 37^{\prime}$ N 60²2'18'W, 17 Apr 2008, H. LópezFernández, D. Taphorn, E. Liverpool, K. Kramer \& C. Thierens.

Paratypes. ROM 84965, 1, $57.5 \mathrm{~mm} \mathrm{SL}$, presumably male, same data as holotype. AUM 49999 (ex ROM 83692), 1, 50.0 mm SL, immature, upper Mazaruni River drainage, Kukui River, night collection near Philipai, 05²1'37'N 60²2'18'W, 15 Apr 2008, D. Taphorn, E. Liverpool \& C. Thierens.

Diagnosis. Neblinichthys echinasus can be separated from all other Neblinichthys except $N$. brevibracchium, by having a pigmentation pattern on the abdomen consisting of large white spots and vermiculations over a dark gray or black background in adult males ( $v s$. abdomen with small brown spots and vermiculations or plain); by lacking odontodes on the opercle (rarely one odontode present, $v s$. the exposed portion of the opercle completely covered by odontodes), by completely lacking the iris operculum ( $v s$. iris operculum small or at least the dorsal rim of the pupil straight), and internares width/head length (6.2-6.7\% vs. 7.6-15.5\%, see Tables 1-2). It is distinguished from $N$. brevibracchium by a larger dorsal-

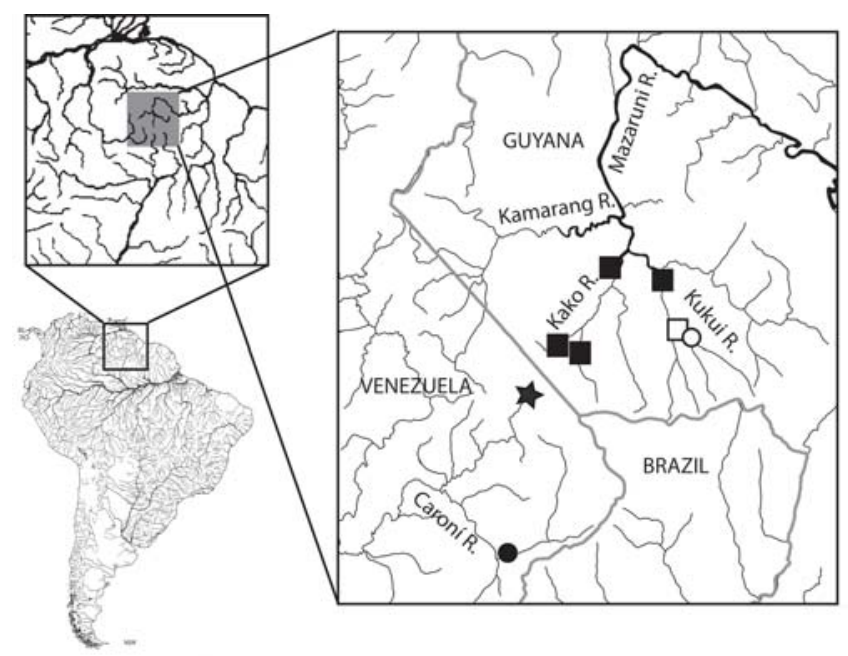

Fig. 2. Distribution of Neblinichthys species in the Caroní and Mazaruni basins of Venezuela and Guyana, respectively. $\operatorname{Star}=N$. roraima, black circle $=N$. yaravi, empty circle $=$ type-locality of $N$. echinasus, new species, empty square = type-locality and black squares $=$ paratype localities of $N$. brevibracchium, new species. 
Table 2. Morphometric features of Neblinichthys pilosus $(\mathrm{N}=6), N$.roraima $(\mathrm{N}=4)$, and $N$.yaravi $(\mathrm{N}=8)$. Landmarks are the numbered landmarks in Armbruster (2003). Some N. roraima have completely adnate barbels, resulting in a measurement of zero for barbel length.

\begin{tabular}{|c|c|c|c|c|c|c|c|}
\hline \multirow[b]{2}{*}{ Landmarks } & \multirow[b]{2}{*}{ Feature } & \multicolumn{2}{|c|}{ N. pilosus } & \multicolumn{2}{|c|}{$N$. roraima } & \multicolumn{2}{|c|}{ N. yaravi } \\
\hline & & Mean \pm SD & Range & Mean \pm SD & Range & Mean \pm SD & Range \\
\hline $1-20$ & $\mathrm{SL}(\mathrm{mm})$ & 55.5 & $49.1-61.9$ & 43.7 & $38.7-46.3$ & 48.4 & $31.0-75.0$ \\
\hline \multicolumn{8}{|c|}{ Percents of standard length } \\
\hline $1-10$ & Predorsal length & $44.4 \pm 1.0$ & $42.8-45.3$ & $47.0 \pm 2.2$ & $44.9-49.1$ & $43.6 \pm 0.9$ & $42.9-45.6$ \\
\hline $1-7$ & Head length (HL) & $34.9 \pm 0.9$ & $33.4-36.1$ & $34.4 \pm 0.7$ & $33.4-35.0$ & $34.5 \pm 1.1$ & $33.4-37.0$ \\
\hline $7-10$ & Head-dorsal length & $9.6 \pm 1.3$ & $7.9-11.2$ & $14.1 \pm 3.0$ & $11.2-17.7$ & $9.4 \pm 0.3$ & $8.9-9.7$ \\
\hline $8-9$ & Cleithral width & $29.1 \pm 1.5$ & $26.7-31.1$ & $26.2 \pm 0.2$ & $25.9-26.3$ & $31.4 \pm 1.3$ & $29.1-33.4$ \\
\hline $1-12$ & Head-pectoral length & $28.5 \pm 1.4$ & $27.3-30.8$ & $29.4 \pm 0.4$ & $29.2-30.0$ & $26.7 \pm 1.6$ & $25.1-30.4$ \\
\hline $12-13$ & Thorax length & $23.0 \pm 1.5$ & $21.3-25.3$ & $25.5 \pm 0.5$ & $25.0-25.9$ & $23.9 \pm 0.8$ & $22.8-25.0$ \\
\hline $12-29$ & Pectoral-spine length & $24.1 \pm 2.2$ & $22.1-27.6$ & $21.9 \pm 1.0$ & $20.5-22.8$ & $24.5 \pm 1.2$ & $22.4-25.8$ \\
\hline $13-14$ & Abdominal length & $23.7 \pm 1.2$ & $22.6-26.0$ & $22.9 \pm 1.0$ & $21.8-23.8$ & $23.2 \pm 1.5$ & $20.8-25.4$ \\
\hline $13-30$ & Pelvic-spine length & $25.9 \pm 2.2$ & $23.6-29.0$ & $21.1 \pm 1.5$ & $20.1-23.4$ & $23.9 \pm 1.3$ & $22.1-25.5$ \\
\hline $14-15$ & Postanal length & $33.8 \pm 0.8$ & $32.8-34.9$ & $31.6 \pm 1.2$ & $30.0-32.8$ & $33.3 \pm 2.6$ & $30.8-38.0$ \\
\hline $14-31$ & Anal-fin spine length & $12.0 \pm 2.7$ & $9.0-16.0$ & $7.2 \pm 0.4$ & $7.0-7.5$ & $8.9 \pm 1.8$ & $6.3-11.0$ \\
\hline $10-12$ & Dorsal-pectoral distance & $28.6 \pm 1.3$ & $26.5-30.5$ & $29.3 \pm 1.1$ & $28.5-30.8$ & $27.1 \pm 0.6$ & $25.8-27.8$ \\
\hline $10-11$ & Dorsal-spine length & $24.3 \pm 2.4$ & $20.4-27.4$ & $22.6 \pm 0.7$ & $22.0-23.6$ & $24.1 \pm 1.7$ & $20.9-26.8$ \\
\hline $10-13$ & Dorsal-pelvic distance & $19.4 \pm 2.1$ & $15.5-21.0$ & $19.0 \pm 0.9$ & $17.7-19.9$ & $19.9 \pm 1.8$ & $16.4-21.9$ \\
\hline $10-16$ & Dorsal-fin base length & $22.9 \pm 1.2$ & $20.8-24.0$ & $19.3 \pm 1.1$ & $17.8-20.1$ & $24.3 \pm 1.5$ & $22.0-26.6$ \\
\hline $16-17$ & Dorsal-adipose distance & $18.0 \pm 1.0$ & $16.5-19.6$ & $19.8 \pm 0.8$ & $18.7-20.5$ & $19.4 \pm 1.2$ & $17.2-21.0$ \\
\hline $17-18$ & Adipose-spine length & $7.7 \pm 1.5$ & $6.2-9.7$ & $8.7 \pm 2.3$ & $6.4-11.8$ & $8.4 \pm 0.6$ & $7.1-9.0$ \\
\hline $17-19$ & Adipose-up. caudal distance & $14.6 \pm 1.2$ & $13.0-15.9$ & $16.8 \pm 0.8$ & $15.7-17.5$ & $15.8 \pm 1.4$ & $13.4-17.5$ \\
\hline $15-19$ & Caudal peduncle depth & $10.0 \pm 0.8$ & $9.2-11.1$ & $10.6 \pm 1.5$ & $8.9-12.2$ & $9.0 \pm 0.7$ & $8.1-10.0$ \\
\hline $15-17$ & Adipose-low. caudal distance & $19.9 \pm 1.4$ & $18.1-21.5$ & $18.5 \pm 1.2$ & $17.8-20.2$ & $20.7 \pm 1.2$ & $18.7-22.0$ \\
\hline $14-17$ & Adipose-anal distance & $20.0 \pm 1.5$ & $17.9-21.4$ & $18.0 \pm 0.7$ & $17.3-18.7$ & $20.2 \pm 0.7$ & $19.0-21.1$ \\
\hline $14-16$ & Dorsal-anal distance & $14.0 \pm 0.9$ & $12.4-15.1$ & $13.2 \pm 1.9$ & $11.1-15.7$ & $13.3 \pm 0.9$ & $12.0-14.7$ \\
\hline $13-16$ & Pelvic-dorsal distance & $24.7 \pm 2.1$ & $21.8-27.2$ & $20.8 \pm 1.3$ & $19.0-22.0$ & $25.7 \pm 5.2$ & $22.1-38.0$ \\
\hline \multicolumn{8}{|c|}{ Percents of head length } \\
\hline $5-7$ & Head-eye length & $31.0 \pm 1.3$ & $29.8-33.6$ & $29.2 \pm 4.0$ & $23.5-32.2$ & $29.3 \pm 1.0$ & $27.3-30.8$ \\
\hline $4-5$ & Orbit diameter & $13.2 \pm 0.9$ & $12.2-14.3$ & $11.8 \pm 0.7$ & $11.1-12.8$ & $13.8 \pm 0.8$ & $12.4-15.0$ \\
\hline $1-4$ & Snout length & $49.8 \pm 2.9$ & $45.4-52.7$ & $42.9 \pm 1.9$ & $41.4-45.7$ & $46.8 \pm 2.1$ & $44.6-50.7$ \\
\hline $2-3$ & Internares width & $14.7 \pm 0.8$ & $13.4-15.5$ & $10.1 \pm 1.1$ & $8.8-11.5$ & $8.2 \pm 0.6$ & $7.6-9.2$ \\
\hline $5-6$ & Interorbital width & $32.6 \pm 1.9$ & $30.7-35.5$ & $25.8 \pm 2.1$ & $23.5-27.9$ & $41.7 \pm 1.9$ & $39.0-44.6$ \\
\hline $7-12$ & Head depth & $52.4 \pm 2.1$ & $49.5-54.4$ & $45.9 \pm 2.2$ & $43.5-48.2$ & $50.0 \pm 1.1$ & $48.9-52.3$ \\
\hline $1-24$ & Mouth length & $42.9 \pm 4.5$ & $36.2-48.7$ & $40.2 \pm 2.7$ & $38.0-43.9$ & $42.9 \pm 3.3$ & $40.2-49.8$ \\
\hline $21-22$ & Mouth width & $46.7 \pm 3.1$ & $42.8-51.3$ & $45.4 \pm 3.1$ & $41.1-48.1$ & $47.8 \pm 2.4$ & $44.1-50.7$ \\
\hline $22-23$ & Barbel length & $5.9 \pm 1.3$ & $4.3-7.8$ & $1.3 \pm 1.5$ & $0.0-2.9$ & $2.1 \pm 0.5$ & $1.3-2.8$ \\
\hline $25-26$ & Dentary tooth cup length & $13.6 \pm 0.7$ & $12.8-14.3$ & $15.4 \pm 1.6$ & $13.6-17.5$ & $13.9 \pm 0.7$ & $13.1-15.3$ \\
\hline $27-28$ & Premaxillary tooth cup length & $15.2 \pm 1.0$ & $14.0-16.5$ & $14.9 \pm 1.8$ & $13.5-17.4$ & $13.0 \pm 1.3$ & $11.9-15.9$ \\
\hline
\end{tabular}

fin base/SL ratio (24.3-27.0\% vs. 18.1-22.8\%), a smaller dorsalanal distance/SL ratio (11.9-12.5\% vs. 13.7-18.3\%), by having the snout tapering shallowly and continuously from eyes to snout tip ( $v s$. snout decreasing in steep arc just anterior to eyes and then flattening in area anterior of nares; Fig. 3), and by having the adpressed dorsal fin reaching the anterior preadipose plate ( $v s$. not reaching anterior preadipose plate). From $N$. pilosus and $N$. roraima by having the odontodes along the edge of the snout of nuptial males longer than those on the top of the snout (vs. odontodes on the front edge of the snout much longer than those on the sides of the snout; nuptial males not known for $N$. brevibracchium or $N$. yaravi); from $N$. roraima by having one to two preadipose plates (vs. more than four).

Description. Morphometrics presented in Table 1. Meristics based on three known specimens, largest $82.9 \mathrm{~mm}$ SL. Body dorsoventrally flattened. Profile from tip of snout sloping posterodorsally to nares, slightly concave between eyes to posterior margin of supraoccipital; gently convex to dorsalfin origin. From deepest point of body (just anterior to dorsalfin origin), profile slopes gently ventrally in straight line to base of caudal-fin spine. Ventral surface flat or slightly concave to anal-fin origin then straight or slightly concave to base of lower caudal-fin spine. Eyes widely separated, almost completely dorsally oriented, not visible from below. In dorsal profile, head margin forms broad $U$-shape. Body widest just behind pectoral-fin insertion, not narrowing until reaching pelvic-fin insertions, and then tapering to end of caudal peduncle.

Cheek plates strongly evertible (to $90^{\circ}$ from head), with very numerous elongate as well as even more numerous short and medium sized odontodes, longest reaching base of second or third pectoral-fin ray. Snout with slightly rounded ridges from eye to just anterior to nares. Mesethmoid forming rounded ridge along midline anterior to nares. Dorsal rim of orbit slightly higher than interorbital space. Iris operculum absent, making dorsal rim of pupil round.

Mouth moderate in size with narrow premaxillary and dentary tooth cups forming gentle arcs. Premaxillary teeth 34-59; dentary teeth 33-62. Teeth villiform and bicuspid with very short cusps (medial cusp longer than lateral cusp). Edge of oral disk scalloped, and extending to vertical through anterior margin of eye, not extending beyond lateral margins of head. Enlarged 


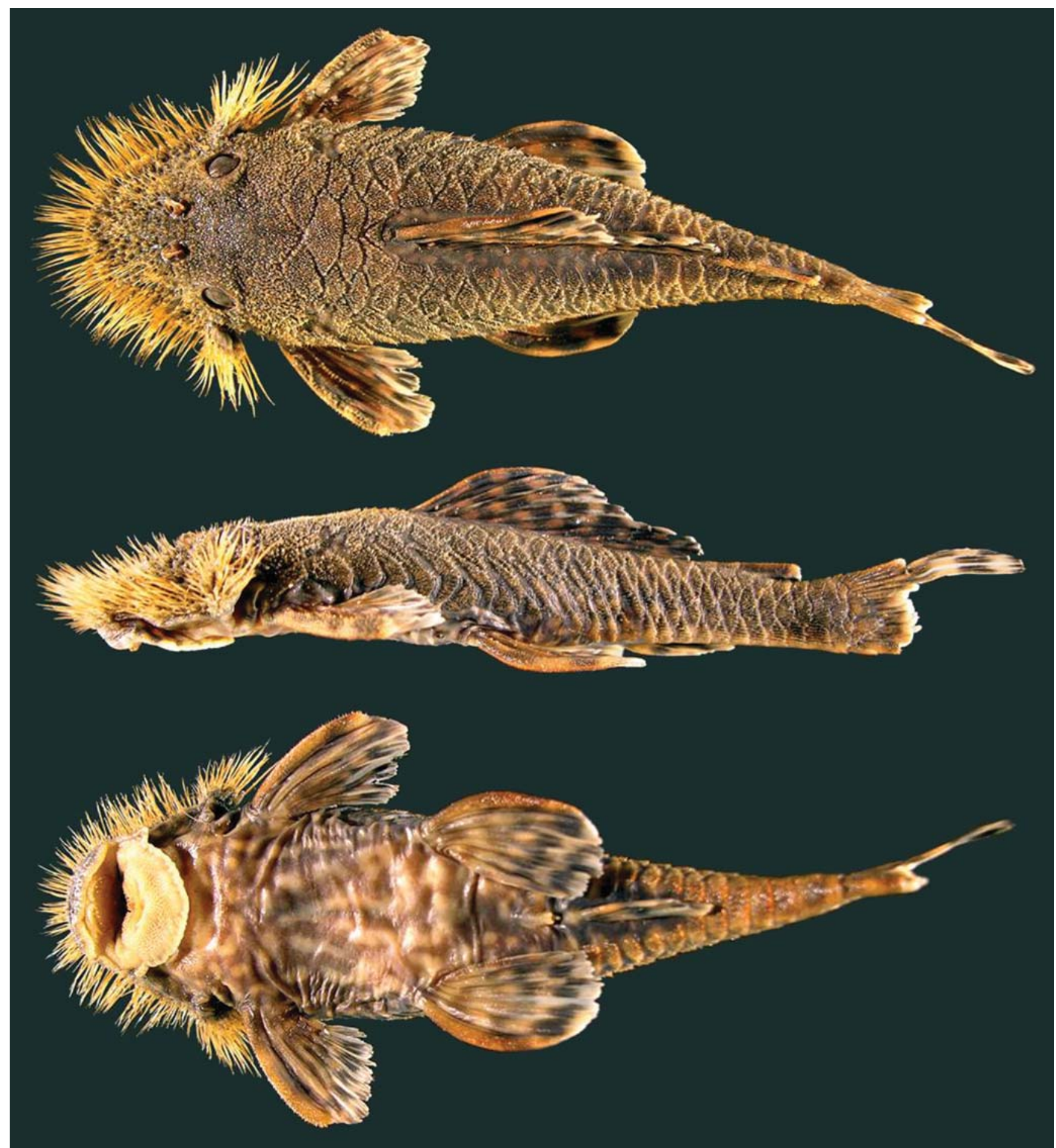

Fig. 3. Neblinichthys echinasus, holotype, CSBD 1652, 82.9 mm SL, Kukui River, near town of Philipai, upper Mazaruni River drainage.

central papilla present in buccal cavity. Maxillary barbel very short, almost completely adnate. Ventral surface of lips papillose. Papillae largest in center of lower lip, decreasing in size radially. No enlarged papillae located behind dentary teeth.

Dorsal fin II,7; dorsal-fin spinelet visible as flat platelet with short odontodes; dorsal-fin lock functional. Dorsal fin short, just reaching preadipose plate when adpressed. First dorsal-fin ray slightly longer than dorsal-fin spine. Pectoral fin I,6; pectoral-fin spine short (slightly shorter or equal to pelvic-fin spine) not reaching pelvic fin when adpressed. Pectoral-fin spine relatively weak with odontodes numerous and of equal size along entire length. Anterior pectoral-fin rays longer than pectoral-fin spine, decreasing to about half of length of spine posteriorly, covered with odontodes that are largest on dorsal margin. Pelvic fin I,5; pelvic-fin spine thickened and covered with odontodes, reaching middle of 


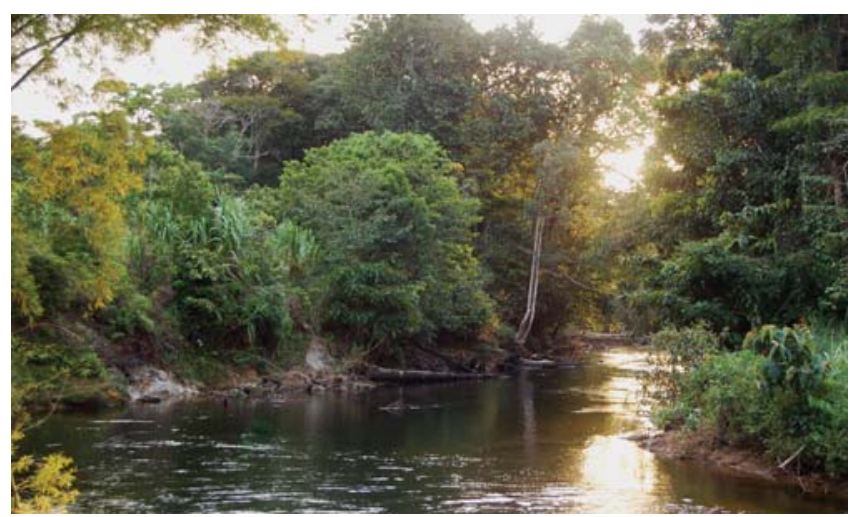

Fig. 4. Neblinichthys habitat in the Kukui River at Philipai $05^{\circ} 21^{\prime} 37^{\prime} \mathrm{N} 60^{\circ} 22^{\prime} 18^{\prime \prime} \mathrm{W}$.

base of anal fin when adpressed; anterior pelvic-fin rays longer than pelvic-fin spine with posterior margin of fin curving out beyond posterior tip of spine. Anal fin I,5; all anal-fin rays longer than weak spine. First anal-fin pterygiophore not exposed to form plate-like structure. Adipose-fin spine straight to slightly curved posteriorly with adipose membrane extending beyond posterior extent of spine. Caudal fin I, 14,I; upper caudal-fin spine shorter than first two upper rays, lower spine longer than all rays, and much longer than upper spine. Dorsal procurrent caudal-fin rays five, ventral procurrent caudal-fin rays three. Posterior caudal-fin margin oblique or slightly concave. Rays of all fins supporting small odontodes.

Median plate series with 21-23 plates. Ventral plates forming gentle arc on caudal peduncle and not forming strong rounded keel. Three rows of plates on caudal peduncle (middorsal and mid-ventral plate series ending at level of adipose fin). Abdomen naked.

Coloration in alcohol. Head, dorsum of body and sides mostly brown with irregular lighter tan blotches. Holotype dark brownish gray with horizontal rows of light spots from behind pectoral-fin insertion to caudal fin on sides. Largest paratype with alternating light and dark brown patches. Ventrum of

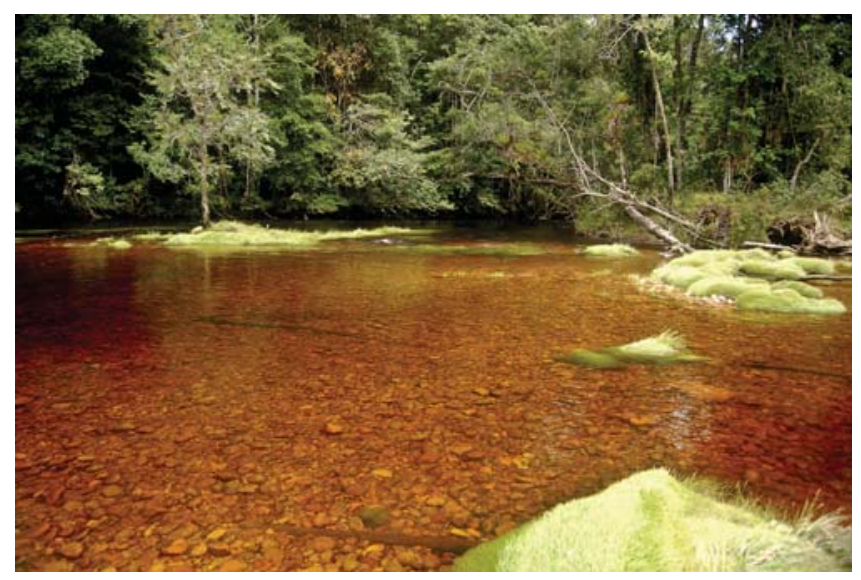

Fig. 5. Neblinichthys habitat in the Waruma River $05^{\circ} 28^{\prime} 32^{\prime \prime} \mathrm{N}$ $60^{\circ} 46^{\prime} 47^{\prime \prime} \mathrm{W}$. holotype dark brown with bold white to cream colored vermiculations and spots. Ventrum of paratypes plain tan. Oral disk with inner papillated surfaces pale tan but brown with white spots on outer anterior margin. All fin spines and rays with alternating wide dark and narrow light bands (pattern most evident in caudal and dorsal fins, least evident in pectorals); fin membranes dark gray in holotype, hyaline in paratypes. Base of anteriormost dorsal-fin membrane black (Fig. 3).

Sexual dimorphism. Presumed males have extremely hypertrophied odontodes along the entire edge of the snout with the odontodes becoming slightly shorter posteriorly. just prior to the evertible cheek plates (Fig. 3). Three rows of hypertrophied odontodes on present on the snout, the medial row is relatively short and located on the mesethmoid; the lateral rows are also relatively short, extending from eyes to nares and then intermediate from nares to snout. The areas between the snout edge and the rows of odontodes have some hypertrophied odontodes, but not as densely packed. The remainder of the dorsal and lateral surfaces of the head have slightly elongated odontodes. Odontodes on the lateral plates are very slightly lengthened in nuptial males. No hypertrophied odontodes are present on the pectoral-fin spines. Presumed males have bolder marking on the abdomen.

Distribution. Known from upper Mazaruni River drainage, Guyana (Fig. 2).

Etymology. From the Latin words echinus meaning sea-urchin or prickly and nasus meaning nose, in reference to the numerous odontodes that adorn males of this species. Epithet used as a noun in apposition, in masculine form.

\section{Discussion}

There are two species of Neblinichthys described from the Caroní basin: Ancistrus yaravi (Steindachner) was recognized by Ferraris (2007) and Armbruster (2008) as the senior synonym of $N$. roraima Provenzano, Lasso \& Ponte. There are, however, two distinct species of Neblinichthys in the Caroní, one with a single preadipose plate and one with four or more preadipose plates. We have examined no nuptial males of the species with one preadipose plates, and nuptial males of the other species were described in the $N$. roraima description (Provenzano et al., 1995). Although Steindachner(1915) described the number of plates in A. yaravi between the dorsal and adipose fins, we believe he is discussing the plates in the dorsal series and not the azygous preadipose plates. There appears to be nothing in the description of $A$. yaravi to indicate which species he examined, there is no drawing of the species, and the type is apparently lost. To be conservative, we are recognizing the species with four or more preadipose plates as $N$. roraima as per its original description and the species with one preadipose plate as Neblinichthys yaravi. We do not offer a redescription of $N$. yaravi or description of a neotype at this time because we feel that this issue requires further study. 
With the recognition of Neblinichthys roraima and $N$. yaravi as distinct and probably sympatric species from the upper Caroní River in the Orinoco basin of Venezuela, and the description of two new species from the upper Mazaruni River of the Essequibo basin, the genus Neblinichthys now contains five species. All are from clear to blackwater highland (Figs. 4, 5) streams draining mountains of the Guiana Shield, and remarkably, four are from the Pacaraima Range that includes Mount Roraima. We suspect that exploration of the rivers of the mountains further south in the Guiana Shield of Guyana, as well as those forming the southern border of Venezuela with Brazil, will reveal either additional populations of these species, or perhaps additional new ones. Even though over 90 years have passed since the first species was described, we know virtually nothing about the reproduction of these species, or to what purpose males employ their special adornments. Only three specimens of Neblinichthys echinasus were available, so we did not clear and stain any specimens; however, the species clearly is a member of Neblinichthys because of the extensive hypertrophied odontodes on the entire dorsal surface of the snout. No other hypostomines have the development of such elongate odontodes on top of the snout.

The two new species of Neblinichthys add to the already long and increasing list of endemic fishes from the upper Mazaruni River. Isolated from both other highland drainages in the Guiana Shield and from the lowland sections of the Essequibo basin, this river harbors what may well be the largest and least known concentration of endemics anywhere in northern South America. Endemic taxa known from the basin include the cichlid genus Mazarunia (Kullander, 1990), the lebiasinid Derhamia hoffmanorum (Géry \& Zarske, 2002), the crenuchid Skiotocharax meizon (Presswell et al., 2000), and the parodontid Apareiodon agmatos (Taphorn et al., 2008). Other endemic taxa from the basin are in the process of being described by the authors. The large number of endemics in the Mazaruni basin suggests this river is of great importance in understanding the biogeographic history of the fishes from the Guiana Shield and of lowland taxa related to them. Incorporation of these new taxa into phylogenetic and biogeographic analyses of the area should shed light on the origin and history of one of the most distinctive and poorly understood fish assemblages in South America.

Unfortunately, the isolation, uniqueness and comparatively small geographic distribution of this fauna also make it extremely vulnerable to the impacts of human activities in the area. We observed extensive damage to the rivers and riparian vegetation caused by gold mining. On land, these operations use high pressure water hoses to break the soil in large pits, and run it through sieves. Then the residue is treated with large quantities of mercury to extract gold before the water is discharged back into the river. Operations on the river are twice as damaging as they use suction to remove sediments from the bottom of the river and pass this material over a sluice where it is treated with mercury to extract gold and then dumped into the river at one spot; thereby changing the course of the river channel. Additionally, the introduction of the lowland cichlid species Cichlasoma bimaculatum for local aquaculture practices has allowed that species, and possibly others, to establish apparently viable populations that may have the potential to displace the native species. There are also plans for possible hydropower dams in this region.

The presence of such high number of endemic species in such a small geographic area strongly speaks for inclusion of the Mazaruni basin into the National Protected Areas System being planned by the Government of Guyana. The expedition to the upper Mazaruni was largely motivated by the recognition that very little was previously known of the fishes from this region. The Centre for the Study of Biological Diversity at the University of Guyana as part of its mission to document the biodiversity of Guyana and promote its conservation is seeking to have the upper reaches of the Mazaruni River included in the boundaries of the Mount Roraima Protected Area currently under consideration by the Government of Guyana. The continuously growing body of evidence suggests that to properly protect the entirety of the biodiversity in the Mount Roraima region, protection must extend to at least cover the full length of the Kukui and Kako Rivers. While collections are yet to be made at the far reaches of the Mazaruni River proper, a precautionary approach would dictate that that area is also in dire need of urgent protection.

Comparative material. Neblinichthys pilosus: AMNH 56137, 69.6 mm SL (holotype), ANSP 157587, 2, 50.3-61.5 mm SL, BMNH 1985.10.15:1-2, 2, 53.0-66.0 mm SL, and USNM 274486, 2, 50.0$57.0 \mathrm{~mm}$ SL, paratypes from Venezuela, Territorio Federal Amazonas, río Negro, río Baria drainage, río Mawarinuma tributary, at Neblina base camp, on right bank in riffle, $00^{\circ} 55^{\prime} \mathrm{N} 66^{\circ} 10^{\prime} \mathrm{W}$, elevation $120 \mathrm{~m}$. Neblinichthys roraima: ANSP 174914, 3, 38.7$44.9 \mathrm{~mm} \mathrm{SL}$ and USNM 317585, 1, $46.4 \mathrm{~mm} \mathrm{SL}$, paratypes from Venezuela, Bolívar, río Caroní system, first creek (quebrada) NW of base camp, Roraima tepui, tributary of río Kukenan, $05^{\circ} 15^{\prime} \mathrm{N}$ $60^{\circ} 40^{\prime} \mathrm{W}$, elevation $1200-1400 \mathrm{~m}$. Neblinichthys yaravi: AUM 36633, 7, 31.0-53.6 mm SL and MCNG 48079, 5 (photographs examined only), Venezuela, Bolívar, Heres, río Yuruani at Highway

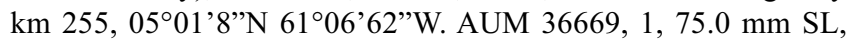
Venezuela, Bolívar, Heres, río Kukenan-Caroní drainage, río Mapuari at Highway $\mathrm{km} \mathrm{268,} \mathrm{about} 38 \mathrm{~km} \mathrm{~N}$ of Santa Elena de Uairen, 045' $38^{\circ}$ ”N 61 ${ }^{\circ} 07^{\prime} 16^{\prime \prime} \mathrm{W}$.

\section{Acknowledgements}

This study is part of a collective effort by scientists from the Center for the Study of Biological Diversity (University of Guyana), the Royal Ontario Museum, Texas A\&M University, Auburn University, and UNELLEZ to assemble a complete inventory of the freshwater fishes of Guyana. We thank E. Liverpool, K. Kramer, L., G. and C. Thierens for help in the field. We are especially thankful to the captains of the villages of Philipai, Jawalla, Kako and Kamarang for providing us with permits for fishing and invaluable logistic support. E. Holm 
and D. Stacey provided curatorial help in processing and cataloguing specimens at the ROM. N. Lujan found and shared obscure references and thoughts on Guiana Shield biogeography. Funding for field work in the Mazaruni River was provided by the United States National Science Foundation grant DEB 0516831 to K. O. Winemiller, R. L. Honeycutt and HLF. Field equipment was partially funded by a grant to DCT from the NSF Planetary Biodiversity Inventory DEB 0315963 “All Catfish Species Inventory", from NSF grant DEB-0107751 to JWA, and by startup funds to HLF from the Royal Ontario Museum's Research General Endowment Fund. Fishing permits were provided by the Environmental Protection Agency of the Government of Guyana and access to Amerindian territories in the upper Mazaruni was kindly provided by the Ministry of Amerindian affairs.

\section{Literature Cited}

Armbruster, J. W. 2003. Peckoltia sabaji, a new species from the Guiana Shield (Siluriformes: Loricariidae). Zootaxa, 344: 1-12.

Armbruster, J. W. 2004a. Phylogenetic relationships of the suckermouth armoured catfishes (Loricariidae) with emphasis on the Hypostominae and the Ancistrinae. Zoological Journal of the Linnaean Society, 141: 1-80.

Armbruster, J. W. 2004b. Pseudancistrus sidereus, a new species from southern Venezuela (Siluriformes: Loricariidae) with a redescription of Pseudancistrus. Zootaxa, 628: 1-15.

Armbruster, J. W. 2008. The genus Peckoltia with the description of two new species and a reanalysis of the phylogeny of the genera of the Hypostominae (Siluriformes: Loricariidae). Zootaxa, 1822: 1-76.

Armbruster, J. W. \& F. Provenzano. 2000. Four new species of the suckermouth armored catfish genus Lasiancistrus (Loricariidae: Ancistrinae). Ichthyological Exploration of Freshwaters, 11(3):241-254.

Armbruster J. W. \& D. C. Taphorn. 2008. A new species of Pseudancistrus from the Río Caroni, Venezuela (Siluriformes: Loricariidae). Zootaxa, 1731: 33-41.

Eschmeyer, W. N. (Ed.) 2008. Catalog of Fishes (electronic version), http://www.calacademy.org/research/ichthyology/catalog/ fishcatsearch.html. Accessed September 18, 2008.
Ferraris, C. J., Jr. 2007. Checklist of catfishes, recent and fossil (Osteichthyes: Siluriformes), and catalogue of siluriform primary types. Zootaxa, 1418: 1-628.

Ferraris, C. J., Jr., I. J. H. Isbrücker \& H. Nijssen. 1986. Neblinichthys pilosus, a new genus and species of mailed catfish from the río Baria system, southern Venezuela (Pisces, Siluriformes, Loricariidae). Revue française d'Aquariologie Herpetologie, 13(3): 69-72.

Géry, J. \& A. Zarske. 2002. Derhamia hoffmannorum gen. et sp. n. - a new pencil fish (Teleostei, Characiformes, Lebiasinidae), endemic from the Mazaruni River in Guyana. Zoologische Abhandlungen; Staatliches Museum für Tierkunde in Dresden, 52: 35-47.

Kullander, S. O. 1990. Mazarunia mazarunii (Teleostei: Cichlidae), a new genus and species from Guyana, South America. Ichthyological Exploration of Freshwaters, 1(1): 3-14.

Leviton, A. E. \& R. H. Gibbs Jr. 1988. Standards in Herpetology and Ichthyology. Standard symbolic codes for institution resource collections in herpetology and ichthyology. Copeia, 1988(1): 280-282.

Lujan, N. K., J. W. Armbruster \& M. H. Sabaj. 2007. Two new species of Pseudancistrus (Siluriformes: Loricariidae) from southern Venezuela. Ichthyological Exploration of Freshwaters, 18(2): 163-174.

Presswell, B., S. H. Weitzman \& T. Bergquist. 2000. Skiotocharax meizon, a new genus and species of fish from Guyana with a discussion of its relationships (Characiformes: Crenuchidae). Ichthyological Exploration of Freshwaters, 11(2): 175-192.

Provenzano, F., C. Lasso \& V. Ponte. 1995. Neblinichthys roraima, a new species of armored catfish (Siluroidei: Loricariidae) from río Kukenan, Venezuela, with considerations about the biogeography of the Guyana Shield. Ichthyological Exploration of Freshwaters, 6(3): 243-254.

Schaefer, S. A. 1997. The Neotropical cascudinhos: systematics and biogeography of the Otocinclus catfishes (Siluriformes: Loricariidae). Proceedings of the Academy of Natural Sciences of Philadelphia, 148: 1-120.

Taphorn, D. C., H. López-Fernández \& C. R. Bernard. 2008. Apareiodon agmatos, a new species from the upper Mazaruni river, Guyana (Teleostei: Characiformes: Parodontidae). Zootaxa, 1925: 31-38. 